\title{
Forefront of $\mathrm{Na}^{+} / \mathrm{Ca}^{2+}$ Exchanger Studies: Regulation Kinetics of $\mathrm{Na}^{+} / \mathrm{Ca}^{2+}$ Exchangers
}

\author{
Satoshi Matsuoka ${ }^{1, *}$ \\ ${ }^{1}$ Department of Physiology and Biophysics, Kyoto University Graduate School of Medicine, Kyoto 606-8501, Japan
}

Received June 14, 2004; Accepted July 27, 2004

\begin{abstract}
Five isoforms of $\mathrm{Na}^{+} / \mathrm{Ca}^{2+}$ exchanger have been identified: NCX1, NCX2, NCX3, NCX-SQ1, and CALX. In all of the exchangers, the $\mathrm{Na}^{+} / \mathrm{Ca}^{2+}$ exchange current, which was recorded in inside-out membrane patches, was regulated by cytoplasmic $\mathrm{Ca}^{2+}$. However, the mode of regulation is different among the exchangers. NCX1, NCX2, and NCX-SQ1 are positively regulated by cytoplasmic $\mathrm{Ca}^{2+}$, but CALX is negatively regulated. NCX3 apparently has both positive and negative regulation mechanisms. In this review, I briefly summarize the $\mathrm{Ca}^{2+}$-dependent regulation mechanisms of the exchangers.
\end{abstract}

Keywords: $\mathrm{Na}^{+} / \mathrm{Ca}^{2+}$ exchanger ( $\left.\mathrm{NCX}\right)$, transporter, regulation, patch clamp

\section{Introduction}

The $\mathrm{Na}^{+} / \mathrm{Ca}^{2+}$ exchange is the main mechanism that extrudes intracellular $\mathrm{Ca}^{2+}$ in exchange for extracellular $\mathrm{Na}^{+}$. At present, five isoforms of $\mathrm{Na}^{+} / \mathrm{Ca}^{2+}$ exchanger (NCX) have been identified: NCX1 (1), NCX2 (2), NCX3 (3), NCX-SQ1 (4), and CALX (5). NCX1, NCX2, and NCX3 are mammalian isoforms. NCX-SQ1 and CALX were cloned from squid axon and Drosophila, respectively. The electrophysiological properties of these isoforms, which were expressed in Xenopus oocytes or cultured cells, have been extensively studied using the inside-out giant membrane patch technique (6). This technique allows studying the regulation kinetics of the exchangers by cytoplasmic $\mathrm{Na}^{+}$and $\mathrm{Ca}^{2+}$ $\left(\mathrm{Na}^{+}\right.$-dependent inactivation and $\mathrm{Ca}^{2+}$-dependent regulation). The $\mathrm{Na}^{+}$-dependent inactivation and the $\mathrm{Ca}^{2+}$ dependent regulation are common features to all the $\mathrm{Na}^{+} / \mathrm{Ca}^{2+}$ exchange isoforms: NCX1 (7), NCX2 (2), NCX3 (8), NCX-SQ1 (4), and CALX (9). The $\mathrm{Na}^{+}-$ dependent inactivation is characterized as the decay of outward $\mathrm{Na}^{+} / \mathrm{Ca}^{2+}$ exchange current during the cytoplasmic application of $\mathrm{Na}^{+}$. The $\mathrm{Ca}^{2+}$-dependent regulation is characterized as the modulation of outward $\mathrm{Na}^{+} / \mathrm{Ca}^{2+}$ exchange current by cytoplasmic $\mathrm{Ca}^{2+}$. The modes and extents of regulation by cytoplasmic $\mathrm{Ca}^{2+}$ differ among the isoforms. In this review, I briefly

*Corresponding author. FAX: +81-75-753-4349

E-mail: matsuoka@card.med.kyoto-u.ac.jp summarize the $\mathrm{Ca}^{2+}$-dependent regulation mechanisms of NCXs.

\section{Regulation of NCXs by $\mathrm{Ca}^{2+}$}

NCX1 is expressed ubiquitously in many tissues and is a dominant isoform in the heart. The function of NCX1 has been most extensively studied among $\mathrm{Na}^{+} / \mathrm{Ca}^{2+}$ exchange isoforms. The regulation of $\mathrm{Na}^{+} / \mathrm{Ca}^{2+}$ exchange by cytoplasmic $\mathrm{Ca}^{2+}$ can be easily studied by recording the outward $\mathrm{Na}^{+} / \mathrm{Ca}^{2+}$ exchange current in the inside-out patch, namely, exchanging extracellular $\mathrm{Ca}^{2+}$ for cytoplasmic $\mathrm{Na}^{+}$. The submicromolar concentration of cytoplasmic $\mathrm{Ca}^{2+}$ increases the peak amplitude of outward $\mathrm{Na}^{+} / \mathrm{Ca}^{2+}$ exchange current, even though the electrochemical gradient of $\mathrm{Ca}^{2+}$ decreases. The half maximum concentration $\left(\mathrm{K}_{\mathrm{h}}\right)$ for $\mathrm{Ca}^{2+}$ to the increase of peak outward current is approximately $0.2 \mu \mathrm{M}(10,11)$. This effect can be explained by relief of exchanger from an inactive state ( $\mathrm{I}_{1}$ inactivation). The regulatory $\mathrm{Ca}^{2+}$ also increases the steady state amplitude of the $\mathrm{Na}^{+} / \mathrm{Ca}^{2+}$ exchange current by attenuating the $\mathrm{Na}^{+}$-dependent inactivation ( $\mathrm{I}_{2}$ inactivation). The $\mathrm{K}_{\mathrm{h}}$ for $\mathrm{Ca}^{2+}$ to the attenuation of $\mathrm{I}_{2}$ inactivation is higher by one order than the one for $\mathrm{I}_{1}$ inactivation (approximately $2 \mu \mathrm{M} ; 10,11)$. Additionally, the regulatory $\mathrm{Ca}^{2+}$ increases the apparent affinity for cytolpasmic $\mathrm{Na}^{+}(10)$. Figure 1 shows an example of the effect of regulatory $\mathrm{Ca}^{2+}$ on the steady state outward $\mathrm{Na}^{+} / \mathrm{Ca}^{2+}$ exchange 


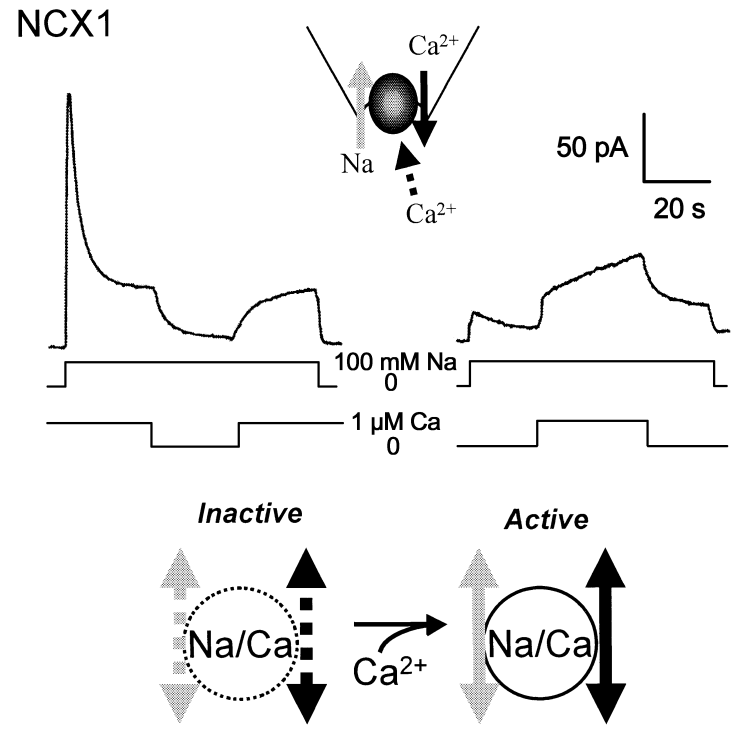

Fig. 1. Outward $\mathrm{Na}^{+} / \mathrm{Ca}^{2+}$ exchange current of $\mathrm{NCX} 1$ recorded in inside-out giant membrane patch. Modified from Hryshko et al. (9).

current (9). The removal of cytoplasmic $1 \mu \mathrm{M} \mathrm{Ca}^{2+}$ attenuated the outward $\mathrm{Na}^{+} / \mathrm{Ca}^{2+}$ exchange current and subsequent re-application of $\mathrm{Ca}^{2+}$ augmented the current. Applying trypsin or chymotrypsin to the cytoplasmic surface of the patch membrane eliminated both the $\mathrm{I}_{1}$ and $\mathrm{I}_{2}$ inactivation and fully activated the $\mathrm{Na}^{+} / \mathrm{Ca}^{2+}$ exchange current. The lower panel of Fig. 1 is a scheme of the positive regulation by cytoplasmic $\mathrm{Ca}^{2+}$. Without cytoplsamic $\mathrm{Ca}^{2+}$, the majority of NCX1 is in an inactive state and cannot exchange $\mathrm{Na}^{+}$for $\mathrm{Ca}^{2+}$. When regulatory $\mathrm{Ca}^{2+}$ binds, $\mathrm{NCX} 1$ moves to an active state and can exchange the ions.

Site directed mutagenesis revealed that the regulatory $\mathrm{Ca}^{2+}$ binds to regions in the large cytoplasmic loop (loop f) $(10,12)$ and that the XIP region is responsible for the $\mathrm{Ca}^{2+}$ regulation (13). The region for alternative splicing may be important to determine the extent of the $\mathrm{Ca}^{2+}$ regulation (14).

NCX2, which is mainly expressed in the brain and skeletal muscles, has an essentially similar $\mathrm{Ca}^{2+}$ regulation to NCX1 (2). The $\mathrm{Ca}^{2+}$ regulation of NCX-SQ1, a squid isoform, is also similar to NCX1 (4). In both isoforms, regulatory $\mathrm{Ca}^{2+}$ augments the outward $\mathrm{Na}^{+} / \mathrm{Ca}^{2+}$ exchange current, even though the $\mathrm{Ca}^{2+}$ dependence of the isoforms is slightly different from that of NCX1.

CALX was cloned from Drosophila melanogaster (5). The CALX is also regulated by cytoplasmic $\mathrm{Ca}^{2+}$, but the effect is opposite to those of the above isoforms. Namely, the outward $\mathrm{Na}^{+} / \mathrm{Ca}^{2+}$ exchange current of CALX was attenuated by regulatory $\mathrm{Ca}^{2+}(9,15)$. Figure 2 shows the $\mathrm{Na}^{+} / \mathrm{Ca}^{2+}$ exchange current recorded with the same experimental protocol as that used in
CalX

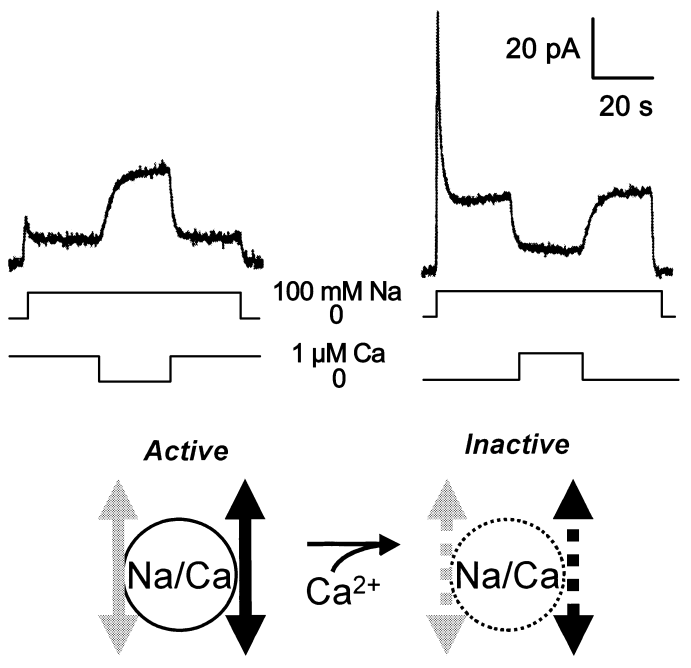

Fig. 2. Outward $\mathrm{Na}^{+} / \mathrm{Ca}^{2+}$ exchange current of CALX recorded in inside-out giant membrane patch. Modified from Hryshko et al. (9).

Fig. 1. The removal of cytoplasmic $\mathrm{Ca}^{2+}$ augmented the outward $\mathrm{Na}^{+} / \mathrm{Ca}^{2+}$ exchange current, and re-application of $\mathrm{Ca}^{2+}$ attenuated the current. This $\mathrm{Ca}^{2+}$ effect is probably not due to the competitive inhibition of $\mathrm{Ca}^{2+}$ to $\mathrm{Na}^{+}$because partial proteolysis by chymotrypsin eliminated the effect. The physiological relevance of this unique effect of regulatory $\mathrm{Ca}^{2+}$ is not clear. However, this is a striking difference to the other isoforms.

The electrophysiological properties of NCX3, which is mainly expressed in the brain and skeletal muscles, have not yet been extensively studied. Linck et al. (8) studied the functional properties of NCX3 in the insideout patch excised from BHK cells expressing NCX3, and they reported that overall functions of NCX3 are similar to those of NCX1 except for the regulation by ATP. NCX3 expressed in BHK cells was not activated by cytoplasmic ATP.

It has been difficult to measure the NCX3 exchange current in the giant membrane patch excised from oocytes. We overcame this problem by increasing the amount of cRNA injected by about ten times, compared to our usual amount. Figure 3 shows a typical record of the outward $\mathrm{Na}^{+} / \mathrm{Ca}^{2+}$ exchange current of $\mathrm{NCX} 3$ recorded with a similar experimental protocol as those used in Figs. 1 and 3. Upon the application of cytoplasmic $1 \mu \mathrm{M} \mathrm{Ca}^{2+}$, the $\mathrm{Na}^{+} / \mathrm{Ca}^{2+}$ exchange current immediately increased, and subsequently decreased within about $5 \mathrm{~s}$. The steady state current was only slightly larger than the current in the absence of $\mathrm{Ca}^{2+}$. Partial proteolysis by trypsin eliminated both the activation and decay of the $\mathrm{Na}^{+} / \mathrm{Ca}^{2+}$ exchange current (data not shown). These data are quite different from 


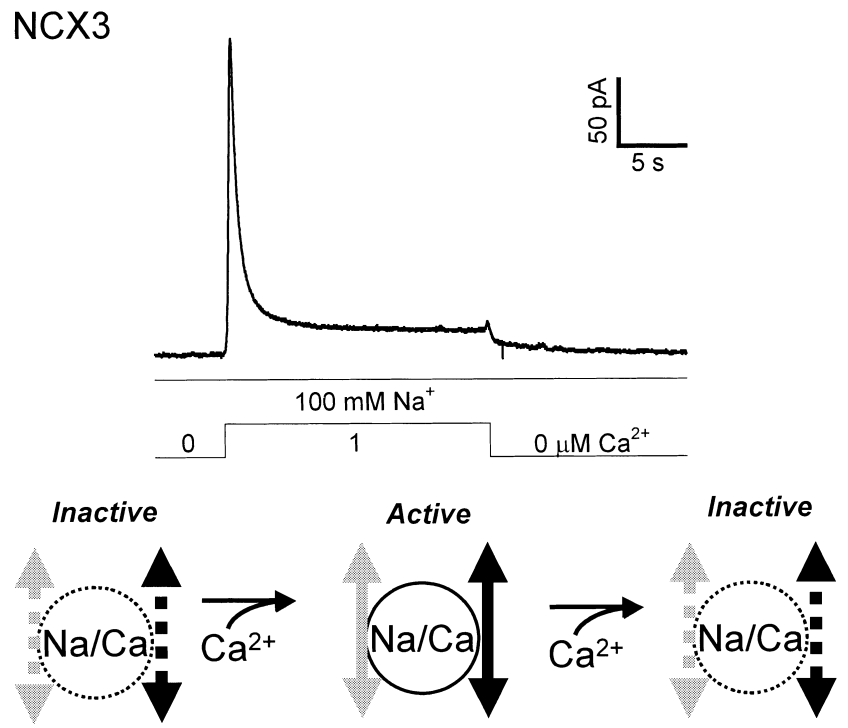

Fig. 3. Outward $\mathrm{Na}^{+} / \mathrm{Ca}^{2+}$ exchange current of $\mathrm{NCX} 3$ recorded in inside-out giant membrane patch.

those of other isoforms. The initial increase by $\mathrm{Ca}^{2+}$ can be explained by the recovery of the exchanger from the $\mathrm{I}_{2}$ inactive state. However, to explain the subsequent decay of $\mathrm{Na}^{+} / \mathrm{Ca}^{2+}$ exchange current, a novel $\mathrm{Ca}^{2+}$ induced inactivation mechanism must be considered. Namely, in the experimental protocol of Fig. 3, the regulatory $\mathrm{Ca}^{2+}$ first activated the NCX3 by relieving the exchanger from the $\mathrm{Ca}^{2+}$ free-induced inactive state ( $\mathrm{I}_{2}$ inactivation), then the regulatory $\mathrm{Ca}^{2+}$ facilitated the exchanger to enter the $\mathrm{Ca}^{2+}$-induced inactive state. Thus, NCX3 is a unique exchanger that possesses the properties of both $\mathrm{Ca}^{2+}$-induced activation and inactivation.

\section{Concluding remarks}

Regulation of NCXs by $\mathrm{Ca}^{2+}$ was briefly discussed. NCX1, NCX2, and NCX-SQ1 are positively regulated by $\mathrm{Ca}^{2+}$. CALX is negatively regulated. NCX3 apparently has both positive and negative regulations by $\mathrm{Ca}^{2+}$. The mechanisms of NCX3 regulation by $\mathrm{Ca}^{2+}$ are complicated, and the physiological relevance of the dual $\mathrm{Ca}^{2+}$ regulation is as yet unknown. Further studies are necessary to clarify the exact mechanisms.

\section{Acknowledgments}

I greatly appreciate Professor Akinori Noma for his encouragement and valuable discussion, and I also thank Drs. Hai-Tian Fan, Satomi Kita, Munekazu Shigekawa, and Takahiro Iwamoto for their collaboration. This work was supported by a Grant-in-Aid for Scientific Research from the Ministry of Education, Culture, Sports, Science, and Technology, Japan, as well as a grant from the Vehicle Racing Commemorative Foundation (to S.M.).

\section{References}

1 Nicoll DA, Longoni S, Philipson KD. Molecular cloning and functional expression of the cardiac sarcolemmal $\mathrm{Na}^{+}-\mathrm{Ca}^{2+}$ exchanger. Science. 1990;250:562-565.

2 Li Z, Matsuoka S, Hryshko LV, Nicoll DA, Bersohn MM, Burke $\mathrm{EP}$, et al. Cloning of the NCX2 isoform of the plasma membrane $\mathrm{Na}^{+}-\mathrm{Ca}^{2+}$ exchanger. J Biol Chem. 1994;269:17434-17439.

3 Nicoll DA, Quednau BD, Qui Z, Xia YR, Lusis AJ, Philipson KD. Cloning of a third mammalian $\mathrm{Na}^{+}-\mathrm{Ca}^{2+}$ exchanger, NCX3. J Biol Chem. 1996;271:24914-24921.

4 He Z, Tong Q, Quednau BD, Philipson KD, Hilgemann DW. Cloning, expression, and characterization of the squid $\mathrm{Na}^{+}-\mathrm{Ca}^{2+}$ exchanger (NCX-SQ1). J Gen Physiol. 1998;111:857-873.

5 Schwarz EM, Benzer S. Calx, a Na-Ca exchanger gene of Drosophila melanogaster. Proc Natl Acad Sci USA. 1997;94: 10249-10254.

6 Hilgemann DW. The giant membrane patch. In: Sakmann B, Neher E. editors. Single-channel recording, 2nd ed. New York: Plenum Press; 1995. p. 307-327.

7 Matsuoka S, Nicoll DA, Reilly RF, Hilgemann DW, Philipson KD. Initial localization of regulatory regions of the cardiac sarcolemmal $\mathrm{Na}^{+}-\mathrm{Ca}^{2+}$ exchanger. Proc Natl Acad Sci USA. 1993;90:3870-3874.

8 Linck B, Qiu Z, He Z, Tong Q, Hilgemann DW, Philipson KD. Functional comparison of the three isoforms of the $\mathrm{Na}^{+} / \mathrm{Ca}^{2+}$ exchanger (NCX1, NCX2, NCX3). Am J Physiol. 1998;274: C415-C423.

9 Hryshko LV, Matsuoka S, Nicoll DA, Weiss JN, Schwarz EM, Benzer S, et al. Anomalous regulation of the Drosophila $\mathrm{Na}^{+}-\mathrm{Ca}^{2+}$ exchanger by $\mathrm{Ca}^{2+}$. J Gen Physiol. 1996;108:67-74.

10 Matsuoka S, Nicoll DA, Hryshko LV, Levitsky DO, Weiss JN, Philipson KD. Regulation of the cardiac $\mathrm{Na}^{+}-\mathrm{Ca}^{2+}$ exchanger by $\mathrm{Ca}^{2+}$. Mutational analysis of the $\mathrm{Ca}^{2+}$-binding domain. $\mathrm{J}$ Gen Physiol. 1995;105:403-420.

11 Fujioka Y, Hiroe K, Matsuoka S. Regulation kinetics of $\mathrm{Na}^{+}-$ $\mathrm{Ca}^{2+}$ exchange current in guinea-pig ventricular myocytes. J Physiol (Lond). 2000;529:611-623.

12 Levitsky DO, Nicoll DA, Philipson KD. Identification of the high affinity $\mathrm{Ca}^{2+}$-binding domain of the cardiac $\mathrm{Na}^{+}-\mathrm{Ca}^{2+}$ exchanger. J Biol Chem. 1994;269:22847-22852.

13 Matsuoka S, Nicoll DA, He Z, Philipson KD. Regulation of cardiac $\mathrm{Na}^{+}-\mathrm{Ca}^{2+}$ exchanger by the endogenous XIP region. J Gen Physiol. 1997;109:273-286.

14 Dyck C, Omelchenko A, Elias CL, Quednau BD, Philipson KD, Hnatowich $\mathrm{M}$, et al. Ionic regulatory properties of brain and kidney splice variants of the $\mathrm{NCX} 1 \mathrm{Na}^{+}-\mathrm{Ca}^{2+}$ exchanger. J Gen Physiol. 1999;114:701-711.

15 Omelchenko A, Dyck C, Hnatowich M, Buchko J, Nicoll DA, Philipson KD, et al. Functional differences in ionic regulation between alternatively spliced isoforms of the $\mathrm{Na}^{+}-\mathrm{Ca}^{2+}$ exchanger from Drosophila melanogaster. J Gen Physiol. 1998;111:691-702. 